\title{
Beclomethasone dipropionate aerosol in childhood asthma
}

\author{
WALTER DICKSON, CATHERINE E. HALL, MARY ELLIS, and \\ ROBERT H. HORROCKS \\ From the Department of Paediatrics, Bolton and District General Hospital, Farnworth, Bolton
}

\begin{abstract}
Dickson, W., Hall, C. E., Ellis, M., and Horrocks, R. H. (1973). Archives of Disease in Childhood, 48, 671. Beclomethasone dipropionate aerosol in childhood asthma. Twenty-five patients with severe childhood asthma were treated with beclomethasone dipropionate. 21 of these children were receiving oral corticosteroid therapy in addition to disodium cromoglycate.

Of the total treated, 21 children improved or maintained their asthma status on this treatment over an average period of 4 months, and were able to reduce and stop their regular oral corticosteroid dosage, but 4 children had to revert to their original therapy.

No systemic or local toxic effects were experienced by any of the children.

Beclomethasone dipropionate appears to be an effective drug in the treatment of severe childhood asthma in those patients who need corticosteroid therapy in addition to disodium cromoglycate.
\end{abstract}

Beclomethasone dipropionate, delivered by aerosol, has been used effectively in the treatment of adults (Clark, 1972; Lal et al., 1972; Morrow Brown, Storey, and George, 1972). This paper reports the results of this treatment in 25 children with severe extrinsic asthma (type 1) in order to determine its effect on their asthma status and suprarenal function, and its ability to replace their need for oral corticosteroid therapy.

\section{Patients}

The experimental nature of the treatment was explained to the parents, and their co-operation in bringing the children regularly and frequently to the clinic was obtained.

There were 25 children selected for the study, 17 boys and 8 girls whose ages ranged from 5 to 16 years. All had severe extrinsic asthma with at least one positive prick test to 14 common antigens. All the children were receiving disodium cromoglycate in conventional doses (3-4 capsules per day), and all had been under observation at the clinic for at least one year. Though all had improved on this treatment, in none could it be said that it had led to a disappearance of their symptoms, and 21 had required the addition of oral corticosteroids (prednisone) to their treatment. In 20 children this had led to a further improvement but not to a complete remission of their symptoms.

For the purposes of this report the children have been

Received 17 April 1973. divided into three groups according to the average daily dose of prednisone given. Group $A$ consisted of 9 children who were receiving an average daily dose of prednisone greater than $5 \mathrm{mg} / \mathrm{m}^{2}$ body surface, reported by Falliers et al. (1963) as capable of producing a deleterious effect on their growth. Group $B$ consisted of 12 children whose average daily dose was less than 5 $\mathrm{mg} / \mathrm{m}^{2}$. Group $C$ consisted of 4 children who had not received prednisone.

No child received an average daily dose greater than 10 $\mathrm{mg} / \mathrm{m}^{2}$. In presenting the results the three groups will be considered separately.

\section{Trial}

The dosage of beclomethasone dipropionate given was $200 \mu \mathrm{g}$ twice daily for children of 8 years of age or more, and $100 \mu \mathrm{g}$ twice daily for younger children. The children were taught how to use the inhaler and none experienced any technical difficulty. When possible the dose of prednisone was gradually withdrawn in the first 2 weeks of the trial.

The children were seen at weekly intervals in the first month of the trial and thereafter at least monthly. At each visit the subjective assessment of the treatment made by both parents and children was recorded, together with any observed side effects. Daily asthma record cards were scrutinized and the children's asthma status assessed. The asthma status was classified into four grades according to the severity of their interval symptoms and freedom from asthma attacks.

Grade $I$ were never free from asthma symptoms. 
Grade II had moderate interval symptoms and occasional attacks of asthma. Grade III had mild asthma symptoms, and Grade IV had virtually no asthma symptoms.

During the first month of the trial weekly recordings of the forced expiratory volume in one second $\left(\mathrm{FEV}_{1}\right)$ and the forced vital capacity (FVC) were made. The haemoglobin, white cell count and differential, plasma protein levels, and liver function tests were assessed on the day before the trial and one month later, as were the 9 a.m. and 9 p.m. plasma hydrocortisone levels (11hydroxycorticosteroids) according to the method of Mattingly (1962).

In some children in whom all values of plasma hydrocortisone were below $12 \mu \mathrm{g} / 100 \mathrm{ml}$ a tetracosactrin (Synacthen) stimulation test was performed-0.25 mg tetracosactrin was given intramuscularly and plasma hydrocortisone levels measured at 0 and 30 minutes later according to the test described by Wood et al. (1965).

\section{Results}

In presenting the results of treatment with beclomethasone dipropionate on the children's asthma status and their need for further oral corticosteroid therapy, three groups will be considered separately. Three periods will be compared: the month before treatment, after one month's treatment, and a varying period averaging 4 months later.

Table I shows the effect in the group A cases. Of the 9 children in this group, 8 had nervouslytriggered asthma and emotional problems contributed significantly to their asthma symptoms. In this group only 1 child (Case 4 ) was free from asthma symptoms, 4 children had moderately severe interval symptoms and occasional attacks, and 1 was never free from asthma symptoms. After one month 7 children were clinically better on beclomethasone dipropionate, 1 child remained the same, and 1 was worse. 4 children had no asthma symptoms during this period. 6 children had stopped oral prednisone therapy but 3 children still needed low-dose prednisone.

At the end of a further period of observation averaging 18 weeks, 7 children maintained their improvement. 2 children deteriorated and had to revert back to high dose oral prednisone. 1 child needed oral prednisone for 2 days on two occasions, once while on holiday abroad and again just before returning to school.

Taking this group as a whole, 4 children became symptom free, 3 maintained their improvement though some asthma symptoms were still present, and 2 had to revert back to their original therapy.

Table II shows the effect of treatment on group B. There were 12 children in this group and before treatment with beclomethasone dipropionate 8 had only mild interval symptoms consisting either of a short period of wheezing on rising in the morning or an occasional disturbed night. 4 had more frequent interval symptoms and an occasional asthma attack. After one month, 6 had improved or maintained their asthma status and 2 had deteriorated. The oral prednisone dose was discontinued in all, but after one month the 2 children who had deteriorated were withdrawn from the trial and resumed their original prednisone therapy.

A further period of observation, averaging 19 weeks, of the remaining 10 children showed that 8 had improved or maintained their asthma status but 2 had had to take oral prednisone, each for a period of 3 days, when asthma symptoms returned. In this group, 8 children received beneficial effect from

\section{TABLE I}

Clinical response and effect on oral prednisone dosage in patients treated with beclomethasone dipropionate. Group $A$ patients received high daily prednisone dosage before trial

\begin{tabular}{|c|c|c|c|c|c|c|c|c|c|}
\hline \multirow{2}{*}{$\begin{array}{l}\text { Case } \\
\text { no. }\end{array}$} & \multirow{2}{*}{ Sex } & \multirow{2}{*}{$\begin{array}{l}\text { Age } \\
(\mathrm{yr})\end{array}$} & \multirow{2}{*}{$\begin{array}{c}\text { Duration } \\
\text { of trial } \\
\text { (wk) }\end{array}$} & \multicolumn{3}{|c|}{ Clinical grading ${ }^{\star}$} & \multicolumn{3}{|c|}{ Daily oral prednisone dose $†$} \\
\hline & & & & Before & $\begin{array}{l}\text { After } 1 \\
\text { month }\end{array}$ & $\begin{array}{c}\text { End of } \\
\text { trial }\end{array}$ & Before & $\begin{array}{l}\text { After } 1 \\
\text { month }\end{array}$ & $\begin{array}{c}\text { End of } \\
\text { trial }\end{array}$ \\
\hline $\begin{array}{l}1 \\
2 \\
3 \\
4 \\
5 \\
6 \\
7 \\
8 \\
9\end{array}$ & $\begin{array}{c}M \\
M \\
M \\
M \\
F \\
M \\
M \\
F \\
F\end{array}$ & $\begin{array}{r}9 \\
14 \\
16 \\
5 \\
10 \\
15 \\
9 \\
8 \\
10\end{array}$ & $\begin{array}{l}24 \\
26 \\
24 \\
20 \\
16 \\
16 \\
22 \\
10 \\
10\end{array}$ & $\begin{array}{l}3 \\
2 \\
1 \\
4 \\
3 \\
2 \\
2 \\
3 \\
2\end{array}$ & $\begin{array}{l}4 \\
3 \\
2 \\
4 \\
2 \\
3 \\
2 \\
4 \\
4\end{array}$ & $\begin{array}{l}4 \\
3 \\
2 \\
4 \\
1 \\
3 \\
1 \\
4 \\
4\end{array}$ & $\begin{array}{l}\text { High } \\
\text { High } \\
\text { High } \\
\text { High } \\
\text { High } \\
\text { High } \\
\text { High } \\
\text { High } \\
\text { High }\end{array}$ & $\begin{array}{l}\text { Nil } \\
\text { Nil } \\
\text { Low } \\
\text { Nil } \\
\text { Low } \\
\text { Nil } \\
\text { Low } \\
\text { Nil } \\
\text { Nil }\end{array}$ & $\begin{array}{c}\text { Nil } \\
\text { Int } \\
\text { Low } \\
\text { Nil } \\
\text { High } \ddagger \\
\text { Nil } \\
\text { High } \neq \\
\text { Nil } \\
\text { Nil }\end{array}$ \\
\hline
\end{tabular}

${ }^{\star} 1$, severe asthma symptoms; 2 , moderate symptoms; 3 , mild symptoms; 4 , no symptoms.

†Oral prednisone dosage: $\mathrm{High}>5 \mathrm{mg} / \mathrm{m}^{2}$ daily; Low $<5 \mathrm{mg} / \mathrm{m}^{2}$ daily; Int, intermittent. $¥$ Withdrawn from trial. 
TABLE II

Clinical response and effect on oral prednisone dosage in patients treated with beclomethasone dipropionate. Group $B$ patients received low daily prednisone dosage before trial

\begin{tabular}{|c|c|c|c|c|c|c|c|c|c|}
\hline \multirow{2}{*}{$\begin{array}{c}\text { Case } \\
\text { no. }\end{array}$} & \multirow{2}{*}{ Sex } & \multirow{2}{*}{$\begin{array}{l}\text { Age } \\
(\mathrm{yr})\end{array}$} & \multirow{2}{*}{$\begin{array}{c}\text { Duration } \\
\text { of trial } \\
\text { (wk) }\end{array}$} & \multicolumn{3}{|c|}{ Clinical grading ${ }^{\star}$} & \multicolumn{3}{|c|}{ Daily oral prednisone doset } \\
\hline & & & & Before & $\begin{array}{l}\text { After } 1 \\
\text { month }\end{array}$ & $\begin{array}{c}\text { End of } \\
\text { trial }\end{array}$ & Before & $\begin{array}{l}\text { After } 1 \\
\text { month }\end{array}$ & $\begin{array}{c}\text { End of } \\
\text { trial }\end{array}$ \\
\hline $\begin{array}{l}10 \\
11 \\
12 \\
13 \\
14 \\
15 \\
16 \\
17 \\
18 \\
19 \\
20 \\
21\end{array}$ & $\begin{array}{c}\mathbf{M} \\
\mathbf{M} \\
\mathbf{M} \\
\mathbf{M} \\
\mathbf{M} \\
\mathbf{M} \\
\mathbf{F} \\
\mathbf{F} \\
\mathbf{M} \\
\mathbf{M} \\
\mathbf{F} \\
\mathbf{M}\end{array}$ & $\begin{array}{l}12 \\
14 \\
12 \\
15 \\
12 \\
14 \\
13 \\
11 \\
10 \\
10 \\
15 \\
14\end{array}$ & $\begin{array}{l}16 \\
16 \\
20 \\
12 \\
16 \\
16 \\
26 \\
26 \\
18 \\
22 \\
13 \\
28\end{array}$ & $\begin{array}{l}3 \\
3 \\
3 \\
3 \\
2 \\
2 \\
3 \\
2 \\
3 \\
3 \\
3 \\
2\end{array}$ & $\begin{array}{l}4 \\
4 \\
3 \\
4 \\
3 \\
1 \\
4 \\
3 \\
4 \\
4 \\
3 \\
4 \\
1\end{array}$ & $\begin{array}{l}4 \\
4 \\
3 \\
4 \\
2 \\
2 \\
4 \\
4 \\
4 \\
4 \\
4 \\
4 \\
2\end{array}$ & $\begin{array}{l}\text { Low } \\
\text { Low } \\
\text { Low } \\
\text { Low } \\
\text { Low } \\
\text { Low } \\
\text { Low } \\
\text { Low } \\
\text { Low } \\
\text { Low } \\
\text { Low } \\
\text { Low }\end{array}$ & $\begin{array}{l}\text { Nil } \\
\text { Nil } \\
\text { Nil } \\
\text { Nil } \\
\text { Nil } \\
\text { Nil } \\
\text { Nil } \\
\text { Nil } \\
\text { Nil } \\
\text { Nil } \\
\text { Nil } \\
\text { Nil }\end{array}$ & $\begin{array}{l}\text { Nil } \\
\text { Nil } \\
\text { Nil } \\
\text { Nil } \\
\text { Int } \\
\text { Lowł } \\
\text { Nil } \\
\text { Int } \\
\text { Nil } \\
\text { Nil } \\
\text { Nil } \\
\text { Lowł }\end{array}$ \\
\hline
\end{tabular}

$\star 1$, severe asthma symptoms; 2 , moderate symptoms; 3 , mild symptoms; 4 , no symptoms.

†Oral prednisone dosage: Low $<5 \mathrm{mg} / \mathrm{m}^{2}$ daily; Int, intermittent.

$\ddagger$ Withdrawn from trial.

TABLE III

Clinical response and need for prednisone in patients treated with beclomethasone dipropionate. Group $C$ patients received no previous prednisone therapy

\begin{tabular}{|c|c|c|c|c|c|c|c|c|c|}
\hline \multirow{2}{*}{$\begin{array}{c}\text { Case } \\
\text { no. }\end{array}$} & \multirow{2}{*}{ Sex } & \multirow{2}{*}{$\begin{array}{l}\text { Age } \\
(\mathrm{yr})\end{array}$} & \multirow{2}{*}{$\begin{array}{c}\text { Duration } \\
\text { of trial } \\
\text { (wk) }\end{array}$} & \multicolumn{3}{|c|}{ Clinical grading ${ }^{\star}$} & \multicolumn{3}{|c|}{ Daily oral prednisone dose } \\
\hline & & & & Before & $\begin{array}{l}\text { After } 1 \\
\text { month }\end{array}$ & $\begin{array}{c}\text { End of } \\
\text { trial }\end{array}$ & Before & $\begin{array}{l}\text { After } 1 \\
\text { month }\end{array}$ & $\begin{array}{c}\text { End of } \\
\text { trial }\end{array}$ \\
\hline $\begin{array}{l}22 \\
23 \\
24 \\
25\end{array}$ & $\begin{array}{l}\mathrm{F} \\
\mathrm{M} \\
\mathrm{F} \\
\mathrm{M}\end{array}$ & $\begin{array}{r}12 \\
12 \\
10 \\
5\end{array}$ & $\begin{array}{l}25 \\
19 \\
26 \\
10\end{array}$ & $\begin{array}{l}2 \\
3 \\
3 \\
2\end{array}$ & $\begin{array}{l}4 \\
4 \\
4 \\
4\end{array}$ & $\begin{array}{l}2 \\
4 \\
4 \\
2\end{array}$ & $\begin{array}{l}\text { Nil } \\
\text { Nil } \\
\text { Nil } \\
\text { Nil }\end{array}$ & $\begin{array}{l}\text { Nil } \\
\text { Nil } \\
\text { Nil } \\
\text { Nil }\end{array}$ & $\begin{array}{c}\text { Intermittent } \\
\text { Nil } \\
\text { Nil } \\
\text { Nil }\end{array}$ \\
\hline
\end{tabular}

^1, severe asthma symptoms; 2 , moderate symptoms; 3 , mild symptoms; 4 , no symptoms.

disodium cromoglycate and beclomethasone dipropionate and this effect was maintained.

Group C comprised 4 children who had never had oral corticosteroids (Table III). All 4 were free from asthma symptoms after one month but the improvement was maintained in only 2 .

The effects of treatment with beclomethasone dipropionate on the plasma hydrocortisone levels before the trial and after one month's treatment is shown in Tables IV, V, and VI.

The results in group A patients are shown in Table IV. Before the trial the majority had morning plasma hydrocortisone levels of about 10 $\mu \mathrm{g} / 100 \mathrm{ml}$, the average level for the group being 9.6 $\mu \mathrm{g} / 100 \mathrm{ml}$, and there was very little diurnal variation. However, after one month the average morning plasma hydrocortisone level was $18.9 \mu \mathrm{g} / 100 \mathrm{ml}$ with 8 out of 9 children showing an increase, and the diurnal variation had returned. 
TABLE V

Plasma hydrocortisone levels before trial and after one month's treatment with beclomethasone dipropionate. Group B patients received low daily prednisone dosage ( $<5 \mathrm{mg} / \mathrm{m}^{2}$ daily) before trial

\begin{tabular}{|c|c|c|c|c|}
\hline \multirow{3}{*}{$\begin{array}{c}\text { Case } \\
\text { no. }\end{array}$} & \multicolumn{4}{|c|}{ Plasma hydrocortisone $(\mu \mathrm{g} / 100 \mathrm{ml})$} \\
\hline & \multicolumn{2}{|c|}{ Before trial } & \multicolumn{2}{|c|}{ After 1 month } \\
\hline & a.m. & p.m. & a.m. & p.m. \\
\hline $\begin{array}{l}10 \\
11 \\
12 \\
13 \\
14 \\
15 \\
16 \\
17 \\
18 \\
19 \\
20 \\
21\end{array}$ & $\begin{array}{c}16 \\
13 \\
\text { Not done } \\
9 \\
12 \\
7 \\
15 \\
5 \\
2 \\
2 \\
5 \\
\text { Not done }\end{array}$ & $\begin{array}{c}7 \\
7 \\
\text { Not done } \\
4 \\
6 \\
6 \\
5 \\
5 \\
2 \\
2 \\
6 \\
\text { Not done }\end{array}$ & $\begin{array}{r}23 \\
18 \\
9 \\
10 \\
9 \\
6 \\
19 \\
18 \\
5 \\
5 \\
17 \\
\text { Not done }\end{array}$ & $\begin{array}{c}5 \\
14 \\
6 \\
3 \\
5 \\
3 \\
5 \\
14 \\
4 \\
5 \\
6 \\
\text { Not done }\end{array}$ \\
\hline
\end{tabular}

In group $B$ cases (Table $V$ ) the results were similar. The average morning plasma hydrocortisone level was $8.6 \mu \mathrm{g} / 100 \mathrm{ml}$ rising to an average of $13.0 \mu \mathrm{g} / 100 \mathrm{ml}$ after one month, 8 out of 10 children showing an increase, and in this group also the diurnal variation had returned.

Group C cases (Table VI) are too few to form any

\section{TABLE VI}

Plasma hydrocortisone levels before trial and after one month's treatment with beclomethasone dipropionate. Group $C$ patients received no previous prednisone therapy

\begin{tabular}{|c|c|c|c|c|}
\hline \multirow{3}{*}{$\begin{array}{c}\text { Case } \\
\text { no. }\end{array}$} & \multicolumn{4}{|c|}{ Plasma hydrocortisone $(\mu \mathrm{g} / 100 \mathrm{ml})$} \\
\hline & \multicolumn{2}{|c|}{ Before trial } & \multicolumn{2}{|c|}{ After 1 month } \\
\hline & a.m. & p.m. & a.m. & p.m. \\
\hline $\begin{array}{l}22 \\
23 \\
24 \\
25\end{array}$ & $\begin{array}{l}14 \\
10 \\
14 \\
18\end{array}$ & $\begin{array}{c}\text { Not done } \\
5 \\
8 \\
5\end{array}$ & $\begin{array}{l}14 \\
11 \\
14 \\
35\end{array}$ & $\begin{array}{r}14 \\
5 \\
4 \\
1\end{array}$ \\
\hline
\end{tabular}

valid conclusions. The average morning plasma hydrocortisone level before the trial was $14 \mu \mathrm{g} / 100$ $\mathrm{ml}$ and after one month $18.5 \mu \mathrm{g} / 100 \mathrm{ml}$. None of the 4 children showed a decrease, indicating that in these 4 cases when beclomethasone dipropionate was the only corticosteroid given it did not cause a fall in the plasma hydrocortisone levels after one month.

The children remaining in the trial who received beclomethasone dipropionate as the sole regular corticosteroid included 5 whose morning and evening plasma hydrocortisone levels remained below $12 \mu \mathrm{g} / 100 \mathrm{ml}$ on repeated testing. These children had tetracosactrin stimulation tests performed, and the plasma hydrocortisone values at 0 and 30 minutes after an intramuscular injection of $0.25 \mathrm{mg}$ tetracosactrin are shown in the Fig. All showed suprarenal responsiveness.

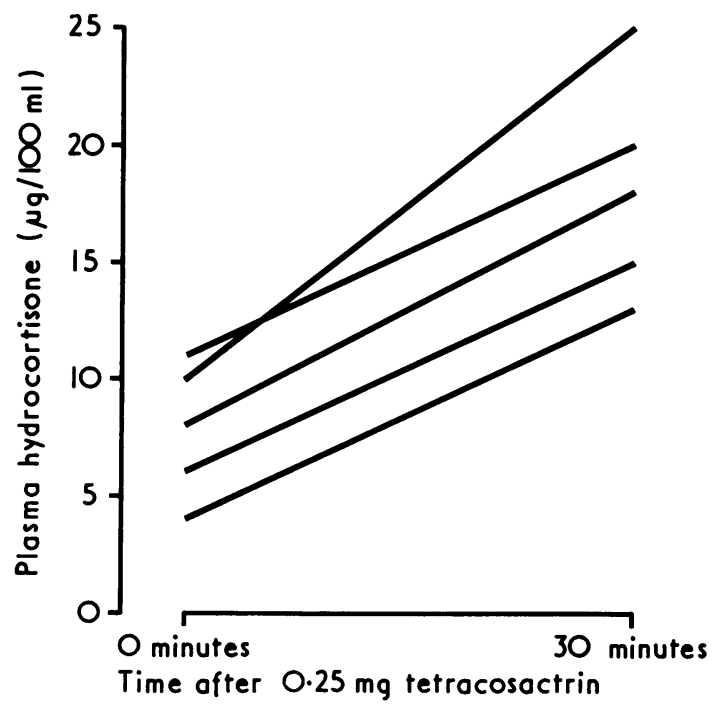

FIG.-Results of tetracosactrin stimulation tests in 5 children whose plasma hydrocortisone levels remained below $12 \mu \mathrm{g} / 100 \mathrm{ml}$ on repeated testing.

In 10 of the 21 children who had maintained their improvement on treatment, an attempt was made to reduce the dose of beclomethasone dipropionate. This was successful in 9 who were stabilized on a dose of $100 \mu \mathrm{g}$ daily at the end of the trial period.

\section{Discussion}

Beclomethasone dipropionate has been shown to be an effective drug in the treatment of asthma in adults. The results of this trial show that it is also effective in childhood asthma, since 17 of the 25 children had a good or a very good response when it was substituted for oral corticosteroids and was given in addition to disodium cromoglycate. Furthermore, this beneficial effect was maintained or even enhanced during the period of observation. 4 children were at least as well as they were on oral corticosteroids, but 4 children had to revert back to oral prednisone. The reason for this is not apparent, for no child had any technical difficulty in taking the aerosol, nor experienced any local irritant effect from it. However, these 4 children had had 


\section{Beclomethasone dipropionate aerosol in childhood asthma}

severe asthmatic episodes in the past in which their oral prednisone and disodium cromoglycate dosages had to be temporarily increased. Also these children, though being highly allergic with multiple positive skin tests, had asthma attacks which were frequently nervously triggered.

The withdrawal of oral prednisone was gradual over the first 2 weeks of the trial, and no child experienced any systemic cortisone withdrawal symptoms, but 2 children complained of worsening of their eczema, and 5 developed a stuffy nose presumably due to an unmasking of allergic rhinitis. No toxic effect was noted in the blood cells and the urea, electrolytes, plasma proteins, and liver function tests remained normal.

The main concern in the long-term use of this drug is whether it would have any adverse local effect on the larynx or mucous membrane of the bronchial tree. None has been shown to occur in animal experiments, and previous investigators have not reported any symptoms suggesting that this had occurred. Nevertheless, until this is known for certain, it seems preferable to limit the continuous use of this drug to one year in the first instance, and to restrict its use to those children who require high or continued corticosteroid doses to control their symptoms.

It has not been possible so far to stop the use of beclomethasone dipropionate or disodium cromoglycate in any of the successfully treated cases without substituting oral prednisone. Any attempt to stop either drug has led to a return of symptoms. 3 children on long-term treatment who were receiving beclomethasone dipropionate as the sole corticosteroid and who had morning plasma hydrocortisone levels within the normal limits have developed some fattening of the face and increase in weight, suggesting, though not proving, that as the mucosal oedema subsides with treatment some absorption of the drug may occur. In these children the dose of the drug was reduced without any return of symptoms.

The effect of treatment on $\mathrm{FEV}_{1}$ and FVC expressed as a percentage of predicted normal values and not reported in the results-showed that before treatment average $\mathrm{FEV}_{1}$ was $63.9 \%$ and after one month's treatment was $77.6 \%$, with 16 out of 25 showing an increase and 2 showing no change; average FVC before treatment was $82 \cdot 1 \%$ and after treatment $92.9 \%$, with 17 out of 25 showing an increase and 2 showing no change. The children as a group, therefore, showed some improvement in these tests as a result of treatment.

\section{Conclusion}

Beclomethasone dipropionate has a beneficial effect in the treatment of childhood asthma, and this effect is maintained at least for a period of 4 months. It is at least as effective as oral corticosteroids in the majority of cases and has a less suppressive effect on the suprarenal glands. No toxic effect was noted during the period of the trial, but caution is indicated in the long-term use of this drug until it is established that no local effect occurs.

We thank Dr. T. R. Malhotra for assistance; Mrs. Joan Lord for secretarial help; and Mr. A. G. Butler and Mr. A. J. Davey, Allen \& Hanburys Limited, for the supply of aerosols and helpful co-operation.

\section{REFERENCES}

Clark, T. J. H. (1972). Effect of beclomethasone dipropionate delivered by aerosol in patients with asthma. Lancet, 1, 1361.

Falliers, C. J., Tan, L. S., Szentivanyi, J., Jorgensen, J. R., and Bukantz, S. C. (1963). Childhood asthma and steroid therapy as influences on growth. American fournal of Diseases of Children, 105, 127.

Lal, S., Harris, D. M., Bhalla, K. K., Singhal, S. N., and Butler, A G. (1972). Comparison of beclomethasone dipropionate aerosol and prednisolone in reversible airways obstruction. British Medical fournal, 3, 314.

Mattingly, D. (1962). A simple fluorimetric method for the estimation of free 11-hydroxycorticoids in human plasma. fournal of Clinical Pathology, 15, 374.

Morrow Brown, H., Storey, G., and George, W. H. S. (1972) Beclomethasone dipropionate: a new steroid aerosol for the treatment of allergic asthma. British Medical fournal, 1, 585.

Wood, J. B., Frankland, A. W., James, V. H. T., and Landon, J. (1965). A rapid test of adrenocortical function. Lancet, 1, 243.

Correspondence to Dr. W. Dickson, Department of Paediatrics, Bolton District General Hospital, Farnworth, Bolton, Lancashire BL4 0JR. 